\title{
Undergraduates Identification of Mainstream Ideology Identity in Colleges and Universities Under Micro-cultural Background*
}

\author{
Laihu Li \\ Baicheng Normal University \\ Baicheng, China
}

\begin{abstract}
The characteristics of decentralization and fragmentation of micro culture not only change the consciousness structure of the mainstream ideological identity of college students, but also impact the education mode of the mainstream ideological identity of college students, thus squeezing the discourse space of the mainstream ideological identity of college students. For this reason, colleges and universities must promote the rationality and communication rationality of mainstream ideology, realize a kind of perception and life of mainstream ideology, and change the expression of the mainstream ideological discourse of college students.
\end{abstract}

Keywords-micro-culture; college students; mainstream; ideology

\section{INTRODUCTION}

Economic globalization, diverse polarization in the world, and social information has made cultural diversity irreversible. Although coexistence of multiculturalism is conducive to ideology borrowing from each other and learning from each other, it also has the risk of weakening the mainstream ideology in China. General Secretary Xi clearly stated: "Ideological work is an extremely important work of the party." At present, the domestic academic community has generally recognized the importance of this issue and has conducted research on the issue of ideological work in colleges and universities in a multicultural context. Many achievements have emerged, but most of them focus on the characteristics and timeliness of ideological work. Cognitively, there is no ground-breaking theoretical opinion on the theoretical direction of ideological work in colleges and universities. This paper makes some reflections on the importance of the ideological work of colleges and universities, the main problems they face, and the reform measures from the perspective of multiculturalism.

*This paper is the phased achievement of the 13th Five-Year Social Science Research Project of the Jilin Provincial Department of Education. Program: The Challenge and Countermeasure of College Students' Mainstream Ideology Identity under the Background of "Micro Culture"

\section{COLLEGES AND UNIVERSITIES ARE AT THE FOREFRONT OF NATIONAL IDEOLOGICAL WORK}

A. Colleges and Universities Are the Places Where Elites Converge, and the Clashes Between Different Thoughts and Cultures Are Frequent and Fierce

This is the frontier position of the country's ideological work.

The fundamental task of colleges and universities is to establish a tree, to bear the important mission of the builders and successors of the socialist cause, and to play an important role in learning, propagating, and implementing the guiding ideology of Marxism. At the same time, colleges and universities are places where elites converge, talented people come into being, and the source of concentration of different ideological and cultural clashes is that culture is the soul of society and values are the essence of culture. General Secretary Xi Jinping pointed out during his inspection at the China University of Political Science and Law that, at present, different ideological and cultural exchanges are mingling with each other, and social thoughts are diverse and varied. The broad masses of young people must build a solid foundation for faith, make up for the calcium of the spirit, and steer the ideology of stability. They must strengthen political determination, strengthen political beliefs, establish firm ideals and convictions, and grasp the direction of life in the "Looking flowers gradually become attractive." Maintaining cultural self-confidence when "you sing and stop me", in the new era, we establish cultural confidence is to adhere to the excellent traditional culture of the Chinese nation, adhere to the Chinese tradition of outstanding culture in the fierce battle between different ideologies and cultures, which is also The Chinese culture of self-reliance, selfexamination, self-esteem and self-improvement.

With the structural reform of China's economic supply side, social conflicts have undergone profound changes. People's autonomy, selectivity, diversity, and variability have increased. Various values, ideas, and cultures have become colorful. College students are sensitive to ideas, openness, and life. Views and values have not yet become completely independent. Societies have complex activities and mainstream ideologies are difficult to control. Some negative 
and decadent ideas have grown. Some college students are confusing in thought and lost in their beliefs. The lack of honesty and integrity in some fields is more prominent. Therefore, it is especially important for colleges and universities to strengthen the ideological work in colleges and universities, enhance the ideological education of college students, and strengthen the political beliefs of college students.

\section{B. Colleges and Universities Are Shouldering the Political Responsibility of Leading Social Trends of Thought}

The success or failure of ideological work will determine whether or not the historic mission of the successor to the socialist industry can be accomplished.

Colleges and universities are important places for disseminating knowledge and inheriting culture. At the same time, they are often the birthplace of various thoughts.

In the distribution center, since the reform and opening up, China's higher education has developed rapidly and is in line with international standards. Various social thoughts have also emerged, showing the characteristics of many types of thoughts, new contents, and rapid changes.

General Secretary Xi addressed the National Conference on Ideological and Political Work in Colleges and Universities in 2016 and pointed out: "To do a good job of ideological and political work in colleges and universities must be based on the facts, because of the times, and because of the new situation." What kind of people is cultivated, how to cultivate people and for who cultivates people is a fundamental issue that every university must face and answer. To strengthen the ideological work in colleges and universities, the most important thing is to stand firmly on the issue of the direction of running a school and to adhere to the guiding ideology of Marxism. Today, diversified social ideologies are confronting each other and stirring up, and the struggle in the ideological field is still acute. To strengthen the ideological and political work in colleges and universities, to lead the social ideological trend must be "real" that is due to the event, timely implementation, "effective" that is, because of the times, emphasis on timeliness, "new" is the new situation, and innovative methods of work.

\section{Colleges and Universities Are the Main Positions of Cultural Inheritance and Innovation}

Strengthening the ideological work in colleges and universities can advance the development of university culture.

In his important speech at the celebration of the 100th anniversary of the establishment of Tsinghua University, General Secretary Hu Jintao emphasized: "To improve the quality of higher education in an all-round way, we must vigorously promote innovation in cultural heritage." This is a new development of higher education thinking and the functions of universities, and is a new era. It is an extremely important new task for our country's higher education to advance with the times.
"The path of the university is in Ming Mingde, Xinmin, and in perfection." As the center of knowledge dissemination and cultural inheritance and innovation, colleges and universities have a tremendous influence on social culture through knowledge dissemination, knowledge creation, and interaction with society. In the era of cultural pluralism, we must strengthen ideological work in universities, promote innovation and creativity in university culture, and provide better socialist services. Inheriting excellent culture, innovating ideological culture, and promoting cultural communication and exchange are both natural missions that universities should undertake and new requirements that the times are evolving and social development has brought to universities.

\section{THE CURRENT COLlEGES AND UNIVERSITIES TO STRENGTHEN THE MAINSTREAM IDEOLOGY OF UNIVERSITY STUDENTS IDENTIFY ISSUES TO BE SOLVED}

\section{A. The Confusion of Cultural Choices}

Contemporary Chinese cultural thoughts are intricate and varied. They are mainly represented by the invasion and infiltration of Western culture, the promotion of the fine traditional Chinese culture, and the establishment and strengthening of Marxist beliefs and guiding status, and are facing severe challenges. Under the impact of diverse culture, some college students in our country have no interest in the study of scientific theory, lack comprehensive understanding of the law of social development, shake ideals and beliefs, and feel lost in the future of socialism and cultural choices.

The hope of our nation and the future of the country depend on the young generation. Whoever wins the youth will win the future. Regarding these phenomena, we must attach great importance to it, face difficulties, and earnestly strengthen the ideological work in colleges and universities, and constantly enhance the university students' political beliefs and values.

\section{B. Multiple Values}

The diversification of the current value orientation of university students can be summarized as selfishness, money worship, hedonistic ism, selfless dedication, and struggle for lofty ideals. If they are allowed to develop, the result will be that the former tends to become more financially richer and deeper and more and more rampant. The latter one is struggling to prove his life value. Therefore, just as Adam Smith, author of The Wealth of Nations, pointed out that competition needs to be subject to "justice constraints," the value orientation must also be given the same emphasis, what should be taken, and what should not be taken. Yes, there is a standard to encourage.

A person with a rational outlook always has a rational mind and will not be disoriented because of emotional impulses. His words and deeds will be reflected in rational thoughts every move. A responsible person will have the courage to take responsibility and predict what responsibility he will assume. He can "get lighter," and he can "appropriate." Because he believes that he has a sense of 
responsibility, he will do everything in earnest and be easy to do. Because of the sense of responsibility, they will understand the importance and will be tolerant, contented, and contented. People who possess these ideas will strive hard for their own ideals. They will not be tempted by material pleasures and selfishness on the road to struggle. They are pursuing more than just material interests.

\section{The Lag of Ideological Education}

At present, the ideological education in some colleges and universities is in a form, the content is lacking in new ideas, and the theoretical updating cannot keep up with the pace of the advancement of the times. The concrete manifestation is that the forms of ideological education are relatively obsolete and single, failing to make full use of the new media such as the network to occupy the highest point of public opinion in a timely manner. The actual effect of ideological work in colleges and universities is far from satisfactory.

Young students are at a crucial stage in the formation of values. They have broad vision, active thinking, fast acceptance of new information, strong curiosity, strong sense of autonomy, and skillful use of the latest information technology tools. All these require the university to update its educational philosophy in a timely manner. The concept of education, on the basis of fully respecting the subjective status of college students and giving them sufficient speaking power, uses modern media and other modern tools to spread mainstream ideology and strengthen ideological education and guidance.

\section{For COLLEGES AND UNIVERSITIES TO STRENGTHEN} THE MAINSTREAM OF IDEOLOGICAL IDENTIFICATION OF THE WORK OF THE REFORM DIRECTION AND MEASURES

In response to the above problems, this paper proposes solutions from the next three levels.

\section{A. Establishing the Cultural Connotation of Mainstream Ideology}

The direction of the efforts of mainstream ideology in colleges and universities should be based on Chinese traditional culture and Marxism as the guiding ideology. Cultural pluralism is not the "law of the jungle" of culture. Instead, it should be based on the situation of specific nationalities and countries to form a cultural model with a dominant culture and a variety of cultures. At present, China's "cultural homeland" is a solution to ideological issues. The fundamental starting point is also the core task of ideological work in colleges and universities.

Contemporary college students have an open mind, active thinking, and strong individuality. We must fully respect the subjective status of contemporary college students and give them enough room to discourse. At the same time, the value of an effective mainstream ideology must be consistent with the inherent spiritual appeal of contemporary college students. The value appeal of the mainstream ideology must be consistent with the individual needs of the college students. It is necessary to establish a smooth expression channel for the appeal of university students.

\section{B. Promoting the Practice of Socialist Core Values}

In order to promote the practice of socialist core values, we must presuppose the basic principles and mechanisms for cultivating and implementing the core values of socialism. On this basis, we must focus on cultivating and implementing the core values of socialism from two perspectives. First of all, it should be people-oriented, proceed from reality, and focus on solving practical problems that teachers and students are concerned about. The second is to cultivate "citizen consciousness" for young students, overcome extreme self-interest, and strengthen "moral education" to overcome widespread lack of integrity and moral anomie, thus creating a "seeing the virtuous thoughts" and "respecting the virtues" Healthy campus culture atmosphere.

At present, our country is in a historical period of profound transformation. We have spent 65 years walking through the path taken by Western capitalism internationally for centuries. The time and space are highly constricted and the curve is overtaking. The problems that have emerged in Western countries for more than one hundred years have also appeared. Various social thoughts have emerged one after another. These diverse cultures and trends of thought represent different interests and value orientations. They are fiercely confrontational, compete for discourse power and dominance, and try to influence reality. The core values of socialism are the soul of the state's ideology. Only by insisting on using socialist core values to lead social ideological trends, develop advanced culture, support healthy culture, change backward culture, and develop and resist decadent cultures, and form a commonweal under the pattern of Marxist guiding ideology. The ideological and cultural patterns that are mutually inclusive and mutually supportive can maximize social consensus and guide college students to establish lofty ideals and beliefs, strong spiritual strength, and basic social moral norms.

\section{Reforming the Implementation Mode of Ideological and Political Education}

The innovation of ideological and political education in universities includes theoretical innovation, formal innovation, and media innovation.

1) Theoretical innovation: Marxist theory must advance with the times, and the latest theoretical results should be used to solve the most recent problems. For example, to make full use of the newly emerging theory of religious cognition, fundamentally dispel the legitimacy of religion in the sense of origin, and provide scientific basis for atheism. This is of great benefit to solving the current widespread problem of college students' religious belief. The ideological work is a work that is oriented toward the spirit and the mind. What is needed is a spring rain, and a silent thing. Combining the characteristics of young people, we will tell 
Chinese stories well so that young people truly understand China and love China.

The young generation will confidently "take over" under the candlelight of China's mainstream values and firmly move toward the future.

2) Formal innovation: Integrate ideological work into campus culture. Through various forms of activities (such as poetry recitations, painting contests, traditional drama performances, etc.), cultural influences can be used to enable young students to complete their spiritual conversion to traditional culture. By promoting good qualities such as integrity and kindness, we will implement positive guidance on values.

3) Media innovation: In the era of the rise of new media, profound changes have taken place in the public opinion, the thinking patterns of college students and the thinking space. This inevitably requires that college teachers change the original single ideological and political education model, and use microfilms, flipping classrooms, and wisdom trees. Media tools attract students' attention and obtain student support, so as to achieve the purpose of ideological and political education. At the same time, colleges and universities are required to establish an active and open campus network culture, carry out various special events in conjunction with the individual needs of contemporary college students, and open blogs. WeChat encourages students to participate, share in time, and conduct live interactive online exchanges to stimulate students' interest. Leveraging on the new platform for new media to integrate ideological and political education into the QQ group of teachers and students and the process of blog and WeChat communication, college teachers must develop blogs, netizen education platforms, and pay close attention to new trends in the development of the Internet. Build a master trusted, manageable and controllable network positions.

\section{CONCLUSION}

In short, in the background of micro-culture, the recognition of undergraduates' mainstream ideology faces not only the opportunities brought by micro-culture but also the challenges of the micro-culture's revolution. In the new situation, how to deepen the comprehension of the changes in ideology, behavior, value, etc. brought by micro-culture and provide more targeted patterns of ideological and political education on that basis becomes a serious problem.

\section{REFERENCES}

[1] Liu Shaojie. The profound changes of social identity in the era of network[J]. Journal of Renmin University of China, 2014(5).

[2] Zhou Xian. The fragmentation of the era and its reflection [J]. Academic Monthly, 2014 (12).

[3] Ulrich Baker: Risk Society [M]. Nanjing: Yilin Press, 2004.

[4] Anthony Giddens. The Consequences of Modernity [M]. Nanjing: Yilin Press, 2000

[5] Xu Xiang. Alienated "Going to the Center": Examining Electronic Utopia[J]. Nanjing Social Sciences, 2010(10).
[6] Zheng Hangsheng. The social significance of structural changes in social practice [N]. Nanfang Daily, 2006-12-07.

[7] Liu Shaojie. The Generation and Change of the Types of Ideology[J]. Academic Monthly, 2011(2). 